\title{
Shock Therapy versus Gradualism: The End of the Debate
}

\author{
Yanyan Zang \& Gang Wang \\ School of Economics, Tianjin Polytechnic University, Tianjin 300384, China \\ Tel: 86-22-8395 6944 E-mail: zangyanyan@hotmail.com
}

\begin{abstract}
China's economy has undergone a fundamental change from planned economy to market economy. The economic strength of the country was intensified constantly. Meanwhile, East European countries and Baltic States advocated radical reforms and rapid transformation. So, it is difficult to say which is better between Shock Therapy and Gradualism. According to different views, this essay will explain the debate in detail.
\end{abstract}

Keywords: Shock Therapy, Gradualism, Transition, Reform

\section{Introduction}

The countries in central and Eastern Europe have undergone fundamental change since the fall of the Berlin Wall. A substantial amount of state property has been privatised and most markets for goods and services are now liberalised. In the transition process, Central and Eastern Europe (CEE) opened to Western business in 1989 expecting a positive contribution to the transition process. Meanwhile, East European countries and Baltic States advocated radical reforms and rapid transformation, i.e. Shock therapy. Unfortunately, the result was these countries suffered 2 to 3 years fall in output, while their CIS counterparts were doing much worse. (Vladimir. 2000)

On the contrary, in the two decades after the initiation of reform and opening to the outside world, China's economy has undergone a fundamental change from planned economy to market economy. The economic strength of the country was intensified constantly. Now China is called the fastest developing country in the world. Why can China avoid recession and get high growth rates? Some people argued that the reason is China takes the step-by-step approach (gradualism) to economic transformation.

So most people think that the Chinese model of economic reform represents a gradual two-track approach, which is different from the radical "Big-Bang" (Shock therapy) approach pursued in Central and Eastern Europe and the former Soviet Union. The result is in a recent debate about relative merit of gradual versus shock therapy approaches to the transition, the gradualist view was overwhelmingly dominant (Roland, 2000 and Sachs and Woo, 1999).

Now, it is time to finish the debate: Shock Therapy Versus Gradualism. This essay will present an explanation from another completely new scale to analysis the reason why CIS countries and China have the different results during the transition process. This essay will demonstrate it with a special explanation in detail.

\section{Why will be the debate finished?}

More than a decade ago, on the eve of transition, there was a famous debate between shock therapists and gradualists. As (Vladimir. 2000) pointed that shock therapists advocated radical reforms and rapid transformation, instead gradualists justified a more cautious and piecemeal approach to reforms. In fact, some East European countries, Baltic states and CIS counterparts suffered nervous recession, even several countries were doing much worse then expectation. So many economists thought gradualism was better than shock therapy; however, some economists argued that the reason that shock therapy failed was those countries did not fulfil the shock therapy carefully and completely.

However, there is an exception is Vietnamese reformers introduced Polish style shock therapy treatment. Comparing with China, these two countries shared a lot of similarities in initial conditions and achieved basically the same results (immediate growth of output without transformational recession) despite different reform strategies. (Vladimir. 2000)

In addition, concentrating on the example of the differing performance of the former Soviet Union (FSU) states, Vladimir (2000) pointed out that liberalization and stabilization of the Baltic States were the best, whereas Uzbekistan was one of the worst procrastinators. However, in Uzbekistan the level of reduction of output was much better than in Baltic's. Furthermore, in Uzbekistan, the economy recovered fast, however, the Baltic's output was still below the pre-recession maximum.

How to explain the series of phenomena? Not only shock therapy but also gradualism cannot simply analysis the examples mentioned above. So here it is necessary to give several explanations from another scale to finish the debate.

\section{Other new explanations}

Since the shock therapy and gradualism cannot explain the above complex phenomena. It is necessary to explain this phenomenon from another scale. Kornai (1998) thought that any generalization about Eastern Europe and the former 
Soviet Union was correct because these countries were very different. One cannot put them all in one basket. The changes in Russia are different from the changes in Poland or Hungary or the Czech Republic, so he thought that people couldn’t oversimplify, contrast China as "gradualist" and Eastern Europe as "Big Bang." And people couldn’t just look at the economy as one big entity, and then either change everything in the economy by a "Big Bang", or change everything gradually. It depends on what component of the economy you are looking at. Therefore, next sections will analysis it from different aspects.

\subsection{Economic transition is only part of the transition.}

According to (Jeffrey Sachs, Wing Thye Woo and Xiaokai Yang.2000), there are two major approaches to study economic transition. One of them surveyed by Dewatripont and Roland (1996), McMillan (1996), Blanchard (1997), Qian (1999), Maskin and Xu (1999), and Roland (2000), uses formal models of endogenous transaction costs to analyze economic transition. But, the formal models are too simple to capture the complexity of institutional. The core of transition is a large-scale shift of constitutional rules (Sachs and Pistor. 1997). So, economic transition (i.e., price liberalization and privatization) is only part of the transition. (Vladimir. 2000) Considering constitutional reform with economic transition is the best way to analysis transformational recession.

Due to the lack of constitutional thinking among economists, some economists easily jump to the conclusions by looking only at the short-term economic effects of different approaches to the transition. Now according to (Vladimir. 2000), by anglicizing the financial strength of government and the trust of businesses, individuals in various institutions and a series of the construction of the aggregate index of the efficiency of institutions, it is useful to understand the importance of the institutional factor. Just as (Polterovich. 1998) argued, the importance of the institutional factor was pointed out more than once for various countries and regions, including transitional economies.

From the exception of the success of gradual reforms in China and shock therapy in Vietnam, it is clear that strong institutional framework does work very well. Furthermore, for the relative success of radical reforms in East European, especially in Central European countries, strong democratic regimes and new market institutions emerged quickly. In addition, comparing Gorbachev reforms with Yeltsin reforms in Russia, the former reforms failed not because they were gradual, but due to the weak of the state institutional capacity leading to the inability of the government to control the flow of evens; the later forms as well as failed not because of the shock therapy, but due to the collapse of the institutions needed to enforce law and order and carry out manageable transition.

In all, when the vacuum in the rule of law via authoritarian regimes (including communist) is filled by gradually building property rights and institutions, the transition process tends to success. However, without the newly developed democratic mechanisms needed to guarantee property rights, contracts and law and order, these countries deemed to have a devastating impact on output.

In a sense, the process of the collapse of output in transition economies is best described by the strength of institutions. However, as mentioned before, there are many differences during the transition economy among the transition countries. So this paper not only focuses on the institution but also concentrates on the initial conditions and distortions in industrial structure and trade patterns to illustrate the collapse of output.

\subsection{Distortions in industrial structure and trade patterns}

Although strong institutional capacity of the state can ensure good performance, the initial conditions cannot be ignoring. Because the worse initial conditions for transformation, the greater the probability of the deep transformational recession, and hence the more likely delays in liberalization.(Janez.1999) The next section will explain it completely.

Among former soviet republics and socialist countries, Vladimir (2000) thought that there existed disproportions inherited from the centrally planned economy (CPE)- high militarization, over industrialization and underdevelopment of the service sector, ' under- openness' of the economy, the perverse structure of trade. And also he mentioned, the greater the magnitude of these distortions inherited from the CPE, the more pronounced the reduction of GDP during the transformational recession. Because there are barriers to capital and labour flows, such as poorly developed banking system and securities market, the lack of accepted bankruptcy and liquidation procedures, and so on. The reallocation of resources is associated with temporary loss of output. The first initial condition will be explained is high defence expenditure.

\subsubsection{High defence expenditure}

It is clear form Vladimir (2000) that, this is one of the most obvious cases of inevitable restructuring leading to the temporary decline of output. In most socialist countries, defence expenditure was very high. So the reduction of this expenditure was not offset by increase in non-defence output. The obvious example is former Soviet Union, the highest defence expenditure, the worst transformation recession comparing Chinese and East European countries' transition. At the same time, Vladimir (2000) though, distortions in industrial structure were very important.

\subsubsection{Distortions in industrial structure}

Generally, all CPEs were over- industrialized at the expense of the underdevelopment of the service sector, especially 
the trade and finance sectors. However, Chinese and Vietnam reforms were not constrained by distorted infrastructure in industry and especially in agriculture. Form the results of the two different reforms it is easy to understand that, during transition period, the countries with huge distortions in fixed capital stock (infrastructure in industry) were doomed to experience transformational recession. As Vladimir (2000) said, even in China large state enterprises in heavy industry proved to be the bottleneck in the whole reform process. So it is clear that the restructuring from industry to services was the major reasons for the transformational recession, rather than depended on shock therapy or gradualism.

\subsubsection{External trade distortions and other distortions}

Next important initial condition is considered by Vladimir (2000) is external trade distortions. Comparing the degree of openness of socialist economies with market economies, it is obvious that in many socialist countries, their external trade was relatively larger than it was in similar market economies. However, as Vladimir (2000) mentioned that, after the transition in most countries, trade was relatively underdeveloped. The reason was distortions existed in the external trade. For example, the prices used in the former Soviet republic trade were completely different from those on international markets. When trade flows among are recalculated in world prices, Russia had a surplus of about 6\% of GDP, whereas 10 out of the remaining 14 former Soviet republics ran absolutely non-sustainable trade deficits in the range of $9 \%$ to $30 \%$ of GDP. (Vladimir. 2000)

In addition, there are many disproportions created by central planning at the micro level. There is a valuable example is the disproportions associated with the size and specialization of enterprises. Compared most enterprises in the CPEs were very large and with China, Vietnam, where enterprises were relatively smaller. As Vladimir (2000) presented the example, less than 500 employees accounted for 25\% or more of total industrial employment in Mongolia, Cuba, and China. On the contrary, half of all employees worked at large enterprises with personnel of over 1000 in Czech, Romania and Soviet republics. So restructuring should have been accompanied by greater reduction of output in East European countries rather than in China and Vietnam.

All in all, differences in performance during transition not only depend on the institutional capacity but also on the pre-transition levels of GDP per capita and distortions in industrial structure and external trade patterns. However, institutional reform is dominant strength. With strong institutions, it turns out that the fall in output in transition economies was associated mostly with the initial conditions

\section{Conclusion}

In a recent debate about relative merit of gradual versus shock therapy approaches to economic transition, different people have different ideas about these two approaches. In fact, it is difficult to use one approach to explain the complex transition economy. So this essay attempts to explain the differences in transition process from another scale.

Due to the lack of constitutional thinking among economists, it is obvious that it will tend to focus on the surface phenomenon. With the strong institutions, accounting for the initial conditions and external environment, it is easy to understand the differences in different countries and different transition economies. In conclusion, forget the shock therapy and gradualism because it is time to apply another approach to analysis the transformational recession.

\section{References}

Blanchard, Olivier. (1997). Economics of Post-Communism Transition, Oxford ～University Press.

Dewatripont, Mathias and Gérard Roland. (1996). Transition as a Process of Large Scale Institutional Change. in David Kreps and Kenneth Wallis (eds.), Advances in Economics and Econometrics: Theory and Applications. Cambridge: Cambridge University Press.

Janez. (1999). Big Bang Vs Gradualism: Turning the Sequence Upside-Down. Slovenia

Jeffrey Sachs, Wing Thye Woo and Xiaokai Yang. (2000). Economic Reforms and Constitutional Transition: Part I. Perspectives, Vol. 1, No. 5.

Kornai Janol. (1998). Unchaining China's SOEs. Magazine on line summer 1998. (1.1).

Maskin, Eric and Chenggang Xu .(1999). Soft Budget Constraint Theories: From Centralization to the Market. Working Paper, Department of Economics, Harvard University.

Qian, Yingyi. (1999). The Institutional Foundations of China's Market Transition. Annual Bank Conference on Development Economics.

Polterovich, Victor. (1998). Institution traps and Economic Reforms. Working Paper \# 98/004. New Economic School, Moscow.

Roland, Gerard. (2000). Politics, Markets and Firms: Transition and Economics. Cambridge, MA, MIT Press.

Sachs, J. and Woo, W.T. (1999). Understanding China's Economic Performance. Journal of Policy Reforms, forthcoming.

Vladimir. (2000).Shock Therapy Versus gradualism: The end of the Debate. Comparative Economic Studies. Published by the Association for Comparative Economic Studies. 